\title{
Stigma, Stigmatisasi, Perilaku Kekerasan dan Ketakutan diantara Orang dengan Gangguan Jiwa (ODGJ) di Indonesia: Penelitian Constructivist Grounded theory
}

\section{Stigma, Stigmatization, Violence and Fear among People with Mental IIIness (PWMI) in Indonesia: A Study on Constructivist Grounded Theory}

\author{
M Arsyad Subu ${ }^{1}$, Imam Waluyo ${ }^{1}$, Adnil Edwin $N^{2}$, Vetty Priscilla ${ }^{3}$, Tilawaty Aprina ${ }^{4}$ \\ ${ }^{1}$ Sekolah Tinggi Ilmu Kesehatan Binawan Jakarta \\ ${ }^{2}$ Fakultas Kedokteran Universitas Andalas Sumatera Barat \\ ${ }^{3}$ Fakultas Keperawatan Universitas Andalas Sumatera Barat \\ ${ }^{4}$ Akademi Kebidanan Aisiyah Pontianak Kalimantan Barat
}

\begin{abstract}
ABSTRAK
Perilaku kekerasan dan perasaan ketakutan serta stigma dan proses stigmatisasi terkait orang dengan gangguan jiwa (ODGJ) banyak dilaporkan. Penelitian ini bertujuan memahami dampak stigma dan proses stigmatisasi terhadap perilaku kekerasan oleh ODGJ dan perilaku kekerasan terhadap ODGJ dan untuk mengetahui ketakutan yang dirasakan oleh ODG serta ketakutan orang lain terhadap ODGJ. Penelitian menggunakan metode Charmaz Constructivist Grounded Theory (CCGT) dengan 30 pasien dan perawat yang bekerja di RS. Marzoeki Mahdi Bogor sebagai partisipan. Metode pengumpulan data dilakukan dengan wawancara semi-terstruktur, dokumen review, memo dan catatan lapangan dan dianalisis dengan Paille grounded theory analisis. Penelitian ini menghasilkan dua tema utama: 1) perilaku kekerasan dan 2) perasaan ketakutan; serta sembilan sub-kategori. Hasil penelitian menunjukkan bahwa perilaku kekerasan dilakukan oleh pasien termasuk terhadap diri sendiri, keluarga, masyarakat, dan tenaga kesehatan. Kekerasan juga dialami oleh penderita dari orang lain. Akibat stigmatisasi, ketakutan dirasakan oleh penderita dan orang lain tehadap penderita. Dampak stigmatisasi dimanifestasikan dengan perilaku kekerasan dan ketakutan yang dialami oleh penderita sendiri, keluarga, dan masyarakat.
\end{abstract}

Kata Kunci: Constructivist grounded theory, gangguan jiwa, ketakutan, perilaku kekerasan, stigma, stigmatisasi

\begin{abstract}
Violent behavior, feeling of fear, stigma, and stigmatization process associated with people with mental illness (PWMI) are widely reported. This research aims to understand the impact of stigma and stigmatization process towards violent behavior by PWMI and violent behavior towards PWMI and to know the fear felt by PWMI and fear of others to PWMI. This study used Charmaz Constructivist Grounded theory (CCGT) method with a total of 30 participants con sisting patients and nurses who work in Marzoeki Mahdi Hospital Bogor. Data collection method was done by semi-structured interviews, document reviews, field notes, and memos. Paille's grounded theory was used for data analysis. This study indicated two major categories, i.e. 1) violent behavior and 2) feeling of fear; as well as nine sub-categories. Study results showed that violent behavior is conducted by patients, including to themselves, families, communities, and health professionals. Violence was also experienced by patients conducted by others. As a result of stigmatization, fear was experienced by patients, and it was also felt by others toward patients. This stigmatization is manifested by violent behavior and fear experienced by patients themselves, family, and community.
\end{abstract}

Keywords: Constructivist grounded theory, fear, mental illness, violent behavior, stigma, stigmatization

Korespondensi: M Arsyad Subu. Sekolah Tinggi Ilmu Kesehatan Binawan Jakarta, Jalan Kalibata Raya No. 25-30 Jakarta Timur DKI Jakarta 13630 Tel. (021) 8010687. Email:arsyad@binawan-ihs.ac.id

DOI: http://dx.doi.org/10.21776/ub.jkb.2018.030.01.10 


\section{PENDAHULUAN}

Gangguan jiwa adalah masalah Kesehatan yang sangat umum terjadi di berbagai negara dan diperkirakan sekitar $12 \%$ dari beban penyakit secara global (1). Prevalensi gangguan jiwa adalah 1,7 per 1.000 dan dengan gangguan jiwa ringan sekitar 6\% dari total populasi Indonesia (2). Pemasalahan ini menjadi kompleks karena orang dengan gangguan jiwa (ODGJ) tidak hanya mendapatkan permasalahan akibat gejala dan penyakitnya, tetapi juga karena adanya stigma dan proses stigmatisasi terhadap mereka (3).

Stigma terhadap orang dengan gangguan jiwa (ODGJ) di Indonesia sangat tinggi yang merupakan manifestasi dari perilaku negatif yang dilakukan oleh keluarga, masyarakat, tenaga kesehatan, institusi kesehatan, lembaga lembaga pemerintah maupun swasta. Di Indonesia, stigma dan stigmatisasi terjadi di kalangan masyarakat umum dan bahkan diantara para profesional kesehatan. Penderita gangguan jiwa seringkali mendapat stigma dari lingkungan sekitarnya. Stigma tersebut melekat pada penderita gangguan jiwa itu sendiri maupun keluarganya (4).

Stigmatisasi adalah suatu proses sosial ketika seseorang yang terpinggirkan telah diberi label sebagai orang yang abnormal atau sesuatu yang memalukan. Kata 'stigma' berasal dari bahasa Yunani kuno, yang barati adanya jarak sosial dimana orang lain tidak mau bergaul dengan orang yang menderita gangguan jiwa (5). Orang yang menderita gangguan jiwa mengalami diskriminasi, sterotif, label dalam kehidupan mereka. Stigma merupakan label negatif yang melekat pada tubuh seseorang yang diberikan oleh masyarakat dan dipengaruhi oleh lingkungan dan merupakan salah satu faktor penghambat dalam penyembuhan klien gangguan jiwa (6).

Para ODGJ mengalami stigmatisasi yang menyebabkan mereka rentan terhadap perilaku kekerasan. Jumlah penderita gangguan jiwa di Indonesia mencapai 2,5 juta dan diperkirakan sekitar $60 \%$ diantaranya mengalami risiko perilaku kekerasan (7). Tanda gejala yang umum perilaku kekerasan adalah ada ide melukai, merencanakan tindakan kekerasan, mengancam, penyalahgunaan obat, depresi berat, marah, sikap bermusuhan/panik, bicara ketus, mengucapkan kata-kata kotor, serta adanya riwayat perilaku kekerasan (8). Suatu kajian penelitian menunjukkan bahwa ODGJ sering menjadi korban daripada sebagai pelaku kekerasan di masyarakat misalnya mereka menjadi korban kekerasan fisik $(9,10)$. Perilaku kekerasan terhadap ODGJ sering terjadi dalam lingkungan keluarga mereka sendiri $(11,12)$. Selain itu, profesi keperawatan memiliki risiko tinggi sasaran perilaku kekerasan oleh pasien mereka (13).

Ketakutan pada penderita berhubungan dengan perilaku kekerasan dan stigmatisasi orang lain. Dalam pelayanan kesehatan jiwa, beberapa penelitian menemukan adanya keterkaitan antara ketakutan perawat dengan hubungan perawat-pasien. Perasaan ketakutan yang dialami oleh perawat dapat mempengaruhi hubungan perawat-pasien (14); yang menghambat dalam pemberian asuhan keperawatan (15-16). Media massa juga memberikan opini masyarakat tentang terkait dengan stigma pada ODGJ (17). Hasil penelitian terdahulu juga menemukan bahwa terdapat hubungan erat antara perilaku kekerasan yang dialami oleh ODGJ dan ketakutan mereka (18). Anggota masyarakat, keluarga dan bahkan professional kesehatan termasuk keperawatan juga merasakan ketakutan terhadap ODGJ (19). Selain itu, banyak ODGJ di Indonesia yang mencari bantuan dari pengobatan tradisional atau alternatif, namun mereka terkadang mengalami perilaku kekerasan oleh terapis-terapis tersebut. Hal ini mengakibatkan ketakutan dan pengalaman traumatis yang dirasakan oleh para ODGJ yang telah berobat terapi tradisional dan alternatif (20).

Tujuan utama dari penelitian ini adalah untuk memberikan analisis pemahaman secara mendalam hubungan stigma dan stigmatisasi gangguan jiwa dengan perilaku kekerasan dan ketakutan (yang dirasakan oleh ODGJ dan oleh orang lain). Review literatur yang telah dilakukan mengungkapkan bahwa penelitian tentang stigma dan stigmatisasi gangguan jiwa terkait perilaku kekerasan dan ketakutan (oleh dan terhadap ODGJ) masih terbatas di Indonesia (4). Penelitian terdahulu belum berfokus pada dampak stigma dan stigmatisasi terhadap perilaku kekerasan dan ketakutan yang dirasakan oleh para ODGJ atau dilakukan oleh orang lain yang behubungan dengan masalah gangguan jiwa di Indonesia.

\section{METODE}

Metode Charmaz Constructivist Grounded theory (CGT) digunakan dalam penelitian ini untuk memberikan pemahaman substantif dan mendalam tentang stigma dan pengalaman stigmatisasi terkait dengan perilaku kekerasan serta perasaan ketakutan terhadap dan oleh ODGJ. Terkait dengan paradigm penelitian, metode CGT ini konsisten dengan epistemologi dan ontologi 'konstruktivisme' yang menempatkan prioritas pada fenomena penelitian dan melihat data dan analisisnya sebagai hal yang dibuat dari pengalaman bersama peneliti dengan para partisipan dan sumber-sumber data yang lain" (21). Menurut Charmaz, metode penelitian ini lebih menekankan pada pendekatan objektivis (objectivist approach). Peran peneliti adalah menemukan kebenaran yang ada di dalam objek penelitian dan meminimalisasi 'kekuatan' (power) (21).

Penelitian ini dilakukan di rumah sakit Marzoeki Mahdi di Bogor provinsi Jawa Barat dan para partisipan penelitian adalah 30 yang terdiri dari 15 pasien yang dirawat dan 15 perawat yang bekerja di rumah sakit. Jumlah 30 partisipan untuk sebuah penelitian grounded theory lebih dari cukup untuk memastikan kejenuhan data (data saturation) (21). Pada awalnya, terdapat 40 partisipan yang telah direkrut. Dalam perjalanannya, 10 orang (tiga perawat dan tujuh ODGJ) mengundurkan diri dengan sukarela karena berbagai alasan. Para partisipan penelitian adalah warga negara Indonesia dan untuk partisipan ODGJ adalah mereka yang mengalami stigma dan proses stigmatisasi dalam kehidupan mereka baik di rumah sakit atau di masyarakat. Metode pengumpulan data penelitian adalah wawancara semi-terstruktur dan dokumen review. Selain itu, pengumpulan data dengan metode memo digunakan untuk mendokumentasikan pengalaman dan untuk laporan secara nyata yang menjelaskan proses berpikir peneliti. Digunakan catatan lapangan (field notes) untuk mencatat observasi dan refleksi data (sebagai triangulasi data untuk meningkatkan probabilitas interpretasi kredibel).

Dalam penelitian ini, metode analisis data grounded theory oleh Paille digunakan untuk menganalisa data kualitatif (22). Paille analisis data ini sangat umum digunakan oleh peneliti grounded teori yang meliputi: 
kodifikasi, kategorisasi, menghubungkan kategori, integrasi, konseptualisasi, dan teorisasi. Analisis data grounded theory memiliki tiga langkah atau tahapan yaitu: 'koding awal, fase menengah, dan pengembangan akhir' (23). Data analisis Paille ini juga dapat dibagi menjadi tiga tahap: kodifikasi dan kategorisasi (koding awal), menghubungkan kategori dan integrasi (fase menengah), konseptualisasi dan teorisasi (pengembangan akhir).

Pada koding awal, langkah kodifikasi adalah proses mengatur kata-kata penting dalam bentuk kode (proses pembentukan semua kode) serta mengidentifikasi adanya tumpang tindih antara kode-kode. Setelah semua kode dibentuk, maka langkah berikutnya adalah kategorisasi. Dalam langkah ini, semua kode dilihat secara rinci dan dimasukkan ke dalam kategori yang sesuai dan terdapat kesamaan. Langkah kategorisasi adalah mengelompokkan semua kode yang muncul terkait atau yang paling penting untuk perilaku kekerasan dan perasaan ketakutan terkait dengan ODGJ. Metode ini membantu mengidentifikasi tumpang tindih antara kode awal dan pembentukan kategori.

Pada fase menengah, langkah menghubungkan kategori adalah suatu proses menghubungkan antara kategori perilaku kekerasan dan perasaan ketakutan melihat persamaan dan perbedaan diantara keduanya. Langkah integrasi adalah untuk mengembangkan skema menyeluruh yang menjelaskan bagaimana masing-masing kategori terkait satu sama lain. Selama tahap analisis ini, memo dan catatan lapangan telah dilihat kembali untuk menganalisis skema agar bisa menemukan benang merah lainnya untuk membangun kerangka penjelasan yang terkait dengan stigmatisasi ODGJ, perilaku kekerasan dan perasaan ketakutan. Dalam langkah konseptualisasi pada tahap pengembangan akhir, hubungan dan keterkaitan antar semua kategori telah selesai dan memungkinkan mulai adanya pemahaman fenomena penelitian. Langkah ini adalah proses menyempurnakan suatu konsep dan kategori untuk pengembangan teori atau pemahaman substantive terkait dengan fenomena penelitian. Akhirnya, langkah teorisasi adalah proses konstruksi atau pembentukan pemahaman secara mendalam. Menurut Charmaz, untuk penelitian dengan Constructivist Grounded theory, fase konseptualisasi dan teorisasi ini tidak harus menciptakan suatu konsep atau teori. Tahap akhir pada fase konseptualisasi dan teorisasi dapat juga dilakukan dengan memberikan suatu pemahaman yang mendalam tentang fenomena sosial atau kehidupan interaksi sosial yang dialami oleh para partisispan sebagaimana pada penelitian ini (21). Studi ini adalah hasil dari representasi terkait stigma ODGJ, perilaku kekerasan dan perasaan ketakutan yang muncul dari perspektif partisipan berdasarkan pengalaman mereka masing-masing. Pemahaman substantif ini dihasilkan setelah peneliti mengikuti setiap langkah data analisis yang berkaitan dengan fenomena dari perspektif partisipan penelitian.

\section{HASIL}

Dengan mengikuti analisis data kualitatif grounded theory secara ketat dan komprehensif, dihasilkan dua kategori utama dan sembilan sub kategori yang saling berhubungan satu sama lain. Kedua kategori utama tersebut adalah 'perilaku kekerasan dan perasaan ketakutan. Perilaku kekerasan adalah suatu keadaan dimana seseorang melakukan tindakan yang dapat membahayakan secara fisik baik terhadap diri sendiri, orang lain maupun lingkungan. Salah satu efek stigma ODGJ adalah perilaku kekerasan yang dilakukan oleh penderita terhadap orang lain termasuk keluarga, perawat dan masyarakat. Sebaliknya, penderita juga mengalami kekerasan dari orang lain terutama oleh para anggota keluarga, masyarakat dan bahkan oleh profesional kesehatan. Kategori perilaku kekerasan memiliki lima subkategori yaitu: kekerasan terhadap diri sendiri (self-harm), kekerasan akibat pasung dan isolasi, kekerasan para ODGJ terhadap barang-barang dan orang lain, kekerasan terhadap ODGJ oleh para pengobat tradisional-alternatif, dan kekerasan yang dilakukan oleh petugas Kesehatan. Kategori perasaan ketakutan memiliki empat sub-kategori yaitu: ketakutan pasien terkait dengan pengobatan mereka, ketakutan keluarga terhadap ODGJ, ketakutan yang dirasakan oleh anggota masyarakat, dan perasaan ketakutan yang dialami oleh petugas kesehatan. Penelitian ini juga menemukan adanya hubungan erat antara perasaan ketakutan oleh orang lain terhadap ODGJ karena risiko perilaku kekerasan dan karena para ODGJ mendapat label berbahaya. Sebaliknya juga terdapat hubungan erat antara perilaku kekerasan yang dialami oleh ODGJ dengan perasaan ketakutan diantara mereka. Perasaan ketakutan di kalangan masyarakat pada ODGJ terutama karena label perilaku kekerasan terkait dengan perasaan ketakutan masyarakat. Untuk lebih jelasnya, maka masing-masing kategori utama dan sub kategori tersebut akan diuraikan pada bagian berikut.

\section{Kategori 1: Perilaku Kekerasan(Violence)}

\section{Sub-kategori 1: Kekerasan terhadap Diri Sendiri}

Ide atau perilaku bunuh diri merupakan manifestasi perilaku kekerasan oleh ODGJ yaitu mereka telah berniat menyakiti dirinya sendiri atau melakukan upaya bunuh diri (suicide) dengan sengaja. Proses stigmatisasi yang dialami oleh para ODGJ dari orang lain menyebabkan timbulnya ide bunuh diri atau menyakiti diri sendiri tersebut. Salah sorang pasien mengungkapkan bahwa rasa takut (fear) terhadap orang lain juga menjadi pencetus ide bunuh diri.

Ya benar sekali pak..... Kadang-kadang saya tidak bisa mengendalikan diri saya sendiri sampai saya memiliki keinginan bunuh diri. Saya telah mencoba untuk bunuh diri tiga kali dengan minum racun tapi saya tidak mati juga. Dengan penyakit jiwa ini, saya memiliki kepercayaan diri yang rendah. Saya merasa bingung juga; .... Dengan orang lain, saya takut. Saya takut melihat orang lain (Ps. 1).

\section{Sub-kategori 2: Kekerasan Akibat Pasung dan Isolasi}

Partisipan penelitian ini mengindikasikan bahwa pasung dan isolasi digunakan oleh orang lain sebagai alat untuk menangani masalah perilaku kekerasan oleh para ODGJ. Para anggota keluarga atau masyarakat mengikat, merantai, atau menempatkan ODGJ dalam balok kayu. Partisipan penelitian ini menunjukkan bukti terjadinya praktek pasung dan isolasi tersebut. Fakta menyatakan bahwa pasien masih sering diikat, dirantai, atau dimasukkan ke dalam balok kayu oleh keluarga mereka serta orang lain.

Ya benar sekali, ....... Hal itu adalah merupakan penderitaan bagi ODGJ. Banyak sekali kita menerima pasien yang telah dipasung ... penderita terikat, dirantai, dimasukkan ke dalam balok kayu; tapi, ada juga pasung di mana penderita ditempatkan di sebuah 
ruangan kecil dan diberikan makanan sekali sehari. Beberapa pasien ini tidak bisa berjalan. Mereka kurus dan kurang gizi. Mereka tidak dapat berbicara. Keluarga mereka kaya; jika mereka ingin membawa pasien [ke rumah sakit], saya yakin bahwa mereka memiliki uang, menurut pendapat saya (Pr. 13).

Salah seorang partisipan penelitian (perawat) mengungkapkan bahwa beberapa ODGJ di masyarakat mengalami stres atau gangguan jiwa ketika telah kembali ke daerahnya setelah beberapa tahun bekerja sebagai di Saudi Arabia.

Pak, saya yang melihat nya sendiri..... dengan mata kepala saya. ODGJ terkait di pilar besar, diletakkan di kandang kambing atau ayam. Oleh karena itu, mereka dikurung mirip dengan seekor kambing.... Saya menjadi saksi dengan kondisi dan situasi ini. Enam pasien yang telah dibawa ke rumah sakit sini [RSMM] .... Daerah ini telah mengirimkan banyak pekerja (TKW) untuk bekerja di luar negeri. Jadi mereka stres atau sakit karena mereka telah bekerja di Arab Saudi..... Mereka stres dan kembali ke Indonesia. Mereka akhirnya dikurung oleh keluarga mereka.... menyedihkan (Pr. 15).

Pasien partisipan menunjukkan fakta adanya kegiatan pasung yang dilakukan terhadap mereka di masyarakat. Salah seorang partisipan (pasien) yang diwawancarai menjelaskan dengan perasaan sedih pengalamannya dipasung.

lya - iya pak.... Itu saya alami sendiri. Saya diikat, dirantai di halaman belakang tanpa sinar matahari dan lain lain. Hal itu dilakukan bersama-sama oleh keluarga dan teman-teman saya. Teman-teman saya juga berada disana saat kejadian itu (Ps.14).

Sub-kategori 3: Kekerasan para ODGJ terhadap Barangbarang dan Orang Lain

Dari hasil wawancara, ODGJ juga telah melakukan kekerasan terhadap fasilitas umum atau barang barang milik orang lain di masyarakat. Salah seorang pasien partisipan mengungkapkan tentang perilaku kekerasan dengan menghancurkan barang barang milik orang lain.

lya pak .... Hmmmm [dengan tertawa], saya melemparkan asbak, disana [tidak jelas].... saya telah meminjamkan satu koma lima juta (uang). la [teman] akan berjanji akan membayar saya kembali dengan cara angsuran. Seratus, lima puluh sekali bayar, lalu kata dia [teman pasien] "uang saya dari BJB [Bank Jawa Barat] adalah lebih banyak" ... Saya jadi marah. Saya tidak bisa mengendalikan diri lagi. Saya jadi marah seperti itu ... kemudian, saya dibawa ke sini [rumah sakit] (Ps. 13).

Selain itu, ODGJ juga telah melakukan perilaku kekerasan terhadap orang lain dan keluarga mereka sendiri dan barang barang milik orang lain. Salah seorang pasien partisipan yang diwawancarai menjelaskan bahwa dia juga telah melakukan kekerasan di masyarakat terhadap orang lain:

.... Saya mematahkan kacamata saya... iya, di rumah. Saya menantang kepala desa dan ketua RT untuk bertarung dengan saya walaupun mereka adalah anggota keluarga saya juga. Saya membawa golok dan clurit untuk membunuh orang-orang tersebut. Saya berkata: "apa yang anda inginkan?"... "Jika anda semua jawara, mari kita bertarung." Mereka tidak berani. Kemudian, saya diserang oleh 100 orang. Akhirnya, saya dibawa ke sini (RSJ)... Ketua RT dan mereka yang akan menyerang saya... Lalu, saya juga dipukul oleh orang-orang tersebut (Ps.1).

ODGJ sebagai partisipan penelitian telah menyadari bahwa dia dibawa oleh orang lain untuk dirawat di rumah sakit jiwa karena perilaku kekerasan tersebut.

...... Saya sampaikan kepada bapak bahwa saya adalah yang paling sulit dalam keluarga ...... dan saya menjadi beban keluarga. Karena kesulitan dalam hidup, saya harus berada di sini (RSJ). Otak saya memiliki banyak masalah. Oleh karena itu, saya marah dan melakukan kekerasan di rumah dan .... Selanjutnya, saya dibawa ke rumah sakit ini (RSJ) (Ps. 11).

Sub-kategori 4: Kekerasan terhadap ODGJ oleh Para Pengobat Tradisional-Alternatif

Banyak ODGJ yang mencari bantuan pengobatan atau terapi kepada para pengobat tradisional tapi mereka mengalami kekerasan yang dilakukan oleh para terapis tersebut. Seorang pasien mengindikasikan telah mengalami kekerasan fisik dari terapis tradisionalalternatif tersebut.

Ya, saya dimandikan tengah malam. Dukun itu menggunakan ilmu sihir ... [tidak jelas], ia memukuli saya juga. Saya dimandikan jam satu malam. Saya tidak tidur. Badan saya dikocok kocok ... diperlakukan mirip dengan kambing. Saya ada disana [terapi tradisionalalternatif] selama satu setengah bulan, namun saya tidak sehat, dan saya tidak lebih baik (Ps. 2).

Tipe lain dari perlakuan tidak manusiawi yang dilakukan oleh terapi tradisional ini (khususnya dukun) adalah dengan melakukan penyek-penyak (pijat keras) pada seluruh tubuh. Hal ini dilakukan untuk melepaskan setan atau roh dari tubuh penderita.

Saya diperlakukan seperti ini [menunjukkan dengan ekspresi] ... kepala saya seperti ini [menunjukkan]... Wah ... panas ... panas, sangat panas [dirasakan oleh pasien]. Kadang dukun melakukan kekerasan ... menggebrak meja ... brukkkkk ... "Kemudian, iblis atau setan dalam tubuh saya keluar," katanya. Mereka [dukun] berpikir bahwa ada setan ... Ya, saudara saya berpikir begitu juga..... (Ps.3).

Sub-kategori 5: Kekerasan yang Dilakukan oleh Petugas Kesehatan

Staf yang bekerja di rumah sakit jiwa juga melakukan kekerasan fisik terhadap pasien mereka. Salah seorang pasien partisipan mengindikasikan bahwa metode pengikatan, pengekangan dan pengasingan digunakan oleh staf dan perawat rumah sakit dalam menangani ODGJ.

Saya telah mengamuk..... Saya dipukul oleh staf dan perawat di K [bangsal). Kepalaku dipukul kursi lipat.... Ya, tangan dan kaki saya diikat karena saya melakukan kekerasan. Saya juga tidak melakukan kesalahan tapi saya diborgol. Ketika saya datang lagi di sini (bangsal), saya juga diborgol. Ada, oleh staf yang bekerja di bangsalK (Ps. 2).

Di rumah sakit, para pasien dengan perilaku kekerasan yang bisa membahayakan akan diisolasi. Hal ini digunakan para staf rumah sakit sebagai pengendalian perilaku 
kekerasan yang dilakukan oleh pasien:

Staf (RSJ) menganggap orang gila sumber bahaya.... Selain itu, mereka menganggap bahwa orang gila, benar-benar gila. Orang gila bukan manusia; mereka harus dihapuskan, mereka harus dibakar, mereka harus ditendang, dan mereka harus ditekan, dan harus ditempatkan di ruangan gelap seperti di $U$ (bangsal).... Ya, itu terjadi, saya seperti babi diseret (Ps. 9).

\section{Kategori 2: Perasaan Ketakutan (Fear)}

Sub-kategori 1: Ketakutan Pasien Terkait dengan Pengobatan Mereka

Para ODGJ sering merasa ketakutan terkait dengan pengobatan terhadap mereka. Hasil wawancara terhadap ODGJ sebagai partisipan, memberikan fakta bahwa mereka mengalami ketakutan terkait dengan pengobatan mereka di rumah sakit jiwa. Anggota masyarakat memaksa ODGJ dan keluarga mereka untuk pergi ke rumah sakit jiwa agar penderita bisa dirawat. Hal ini membuat ODGJ merasa takut dan trauma.

Kata mereka [orang orang yang menjemput paksa pasien] "Anda akan kami jemput untuk mendapatkan pengobatan ... "Kepala desa tyang memerintahkan"... "Kami diwajibkan oleh kepala desa untuk membawa anda ke rumah sakit jiwa. "Disana anda akan cepat sembuh", kata orang-orang itu. "Mengapa saya dibawa, saya bisa melakukannya sendiri" [kata pasien] .... sangat sedih, traumatis [sedih]..... Hal ini merupakan traumatis dan sedih sekali ... Bagi saya (Ps. 12).

Banyak diantara ODGJ mendapatkan pengobatan tradisional selain di rumah sakit. Seorang partisipan penelitian mengungkapkan bahwa dia mengalami trauma terutama adanya kekerasan fisik yang dilakukan oleh terapis selama berobat dengan pengobatan alternatif atau tradisional (dukun).

Saya mengalami ...... [tidak jelas]. Di N [salah satu kota di Jawa], hal itu menakutkan, di daerah terpencil di p[ulau J ... saya mengalami dan tempat itu sangat gelap [dengan ekspresi ketakutan].... Saya takut.... Dan dia [terapis tradisional] adalah mantan penderita jiwa. Dia [terapis] mengatakan: "Ini adalah penyakit gila ....... [tidak jelas];.... Saya ingin melarikan diri.... cara pengobatan aneh. Saya sangat stress saat itu (Ps. 3).

Sub-kategori 2: Ketakutan Keluarga terhadap ODGJ

Adanya perasaan ketakutan bahwa pasien akan mengulangi kekerasannya menyebabkan keluarga merasa tidak nyaman jika penderita berada di rumah. Hidup dalam keluarga dengan salah satu anggota keluarga memiliki gangguan jiwa menimbulkan masalah serius bagi keluarga terutama akibat riwayat perilaku kekerasan oleh ODGJ.

........ [tidak jelas]. Ya, bisa.... karena malu juga ... karena sebagian besar penderita mengganggu anggota masyarakat lain. Umumnya, pasien laki-laki mengganggu komunitas...... dan membuat keluarga merasa tidak nyaman [malu] dengan tetangga mereka. Mereka (keluarga) merasa takut jika pasien bertindak perilaku kekerasan lagi .... Ya pastilah pak, mereka merasa ketakutan. lya kan? (Pr. 11).
Sub-kategori 3: Ketakutan yang Dirasakan oleh Anggota Masyarakat

Dari partisipan penelitian didapatkan informasi bahwa banyak masyarakat umum yang merasa takut kepada ODGJ. Rasa takut ini berkontribusi pada isolasi seorang penderita gangguan jiwa. Mereka (anggota masyarakat) masih percaya bahwa gangguan jiwa adalah penyakit menular dan mereka takut dengan ODGJ akibat keyakinan tersebut.

Di masyarakat luar, orang lain berpikir bahwa pasien masih sakit ..... dan percaya bahwa penyakit jiwa mereka adalah penyakit yang menular seperti penyakit menular lainnya.... Oleh karena itu, mereka (ODGJ) harus diisolasi....... (Pr. 11).

Pasien partisipan juga mengungkapkan bahwa mereka telah dijauhi dan diisolasi oleh bekas teman-teman dan anggota masyarakat karena mereka takut terhadap pasien.

...... Mereka takut terhadap saya. Mereka takut untuk berdebat dengan saya. Mereka takut karena saya orang sakit jiwa. Ya, itu bisa.... Argumen saya tidak diterima; tidak dipahami oleh mereka. Misalnya, jika saya berbicara benar, mereka harus mematuhi saya ...... tidak masalah selama mereka tidak memukul saya (Ps. 5).

Sub-kategori 4: Ketakutan yang Dialami oleh Petugas Kesehatan

Seorang perawat partisipan mengungkapkan bahwa dia percaya ODGJ adalah orang berbahaya seperti yang dirasakan oleh anggota masyarakat umum. Seorang perawat partisipan mengakui bahwa dia berani ketika di rumah sakit tetapi takut ketika berada di masyarakat atau di luar lingkungan rumah sakit.

.... benar benar. Ini fakta pak, benar... Saya punya tetangga dekat dengan rumah saya yang menderita gangguan jiwa dan dia (ODGJ) telah keluar-masuk rumah sakit; pulang sendiri kerumah (dari rumah sakit) beberapa kali... saya sendiri yang bekerja dengan pasien gangguan jiwa, memberi makan dan memandikan mereka dan lain-lain di rumah sakit. Tapi di luar rumah sakit, karena stigma, saya merasa takut pada mereka.... [tertawa] (Pr. 2).

\section{DISKUSI}

Hasil penelitian dengan metode Constructivist Grounded theory (CGT) ini telah menghasilkan dua kategori utama yaitu perilaku kekerasan dan perasaan ketakutan serta sembilan sub kategori (perilaku kekerasan dengan lima sub-kategori dan kategori perasaan ketakutan memiliki empat sub kategori). Kedua kategori perilaku kekerasan dan perasaan ketakutan tersebut sangat erat kaitannya atau saling behubungan satu sama lain terkait dengan adanya stigma dan proses stigmatisasi para ODGJ. Dari hasil penelitian, stigma dan proses stigmatisasi terkait dengan ODGJ terjadi di kalangan keluarga, masyarakat umum termasuk profesional kesehatan khususnya diantara para perawat yang seharusnya memberikan pelayanan optimal terhadap para ODGJ. Kedua kategori perilaku kekerasan dan perasaan ketakutan tersebut sangat erat kaitannya atau saling behubungan satu sama lain yang terkait dengan stigma dan stigmatisasi ODGJ. Dari hasil penelitian, stigma dan proses stigmatisasi terjadi di kalangan keluarga, masyarakat umum termasuk 
profesional kesehatan khususnya diantara para perawat yang seharusnya memberikan pelayanan optimal terhadap para ODGJ. Hasil penelitian membuktikan bahwa perilaku kekerasan telah dilakukan oleh penderita gangguan jiwa terhadap orang orang lain termasuk para keluarga, professional perawat dan masyarakat umum. Namun sebaliknya, penderita juga telah mengalami perilaku kekerasan dari orang lain terutama oleh anggota keluarga mereka, masyarakat umum dan dari profesional kesehatan. Terdapat hubungan yang erat antara perasaan ketakutan oleh orang lain terhadap penderita karena adanya label risiko perilaku kekerasan serta karena ODGJ dianggap berbahaya. Terdapat juga hubungan yang erat antara perilaku kekerasan yang dialami oleh penderita dari orang lain dengan perasaan ketakutan diantara mereka. Sebaliknya, perasaan ketakutan terjadi di kalangan masyarakat umum dan profesional kesehatan karena mereka berpikir akan menerima akibat atau resiko dengan adanya perilaku kekerasan oleh para penderita gangguan jiwa.

\section{Perilaku Kekerasan (Violence)}

Hasil penelitian ini membuktikan bahwa perilaku kekerasan yang terjadi secara luas di masyarakat dan di pelayanan kesehatan telah dilakukan oleh penderita terhadap orang lain atau sebaliknya yang dilakukan oleh oleh orang lain terhadap penderita. Hal ini merupakan salah satu konsekuensi dari adanya stigma dan proses stigmatisasi ODGJ tersebut. Perilaku kekerasan oleh ODGJ adalah keadaan ketika penderita mempunyai riwayat melakukan tindakan yang membahayakan diri sendiri, orang lain atau lingkungan baik secara fisik atau emosional (8). Selain itu, dari hasil penelitian didapatkan informasi bahwa ODGJ melakukan kekerasan terhadap diri mereka sendiri (self harm). Kekerasan mandiri tersebut atau terhadap diri sendiri meliputi ide atau percobaan bunuh diri (suicidal ideation). Seperti halnya penelitian ini, beberapa hasil penelitian lain menunjukkan hasil yang sama terkait ide bunih diri ini. Sebuah penelitian mengungkapkan bahwa percobaan bunuh diri atau melukai diri sendiri (self-harm) ODGJ ini dilakukan sebagai upaya untuk memecahkan permasalahan mereka (24). Penelitian lain di Inggris juga menunjukkan bahwa antara tahun 2003-2013, 18,220 ODGJ telah melakukan bunuh diri (25), dan di berbagai negara, risiko bunuh diri ini meningkat pada ODGJ (26).

Penelitian ini mengindikasikan bahwa ODGJ melakukan kekerasan terhadap keluarga maupun komunitas mereka. Perilaku kekerasan yang dilakukan oleh pasien paling tinggi di pelayanan akut adalah sekitar $10-36 \%$ (27) dan kekerasan oleh ODGJ diarahkan pada orang yang mereka kenal, terutama anggota keluarga (28). Hasil penelitian ini juga menunjukkan bahwa ODGJ melakukan kekerasan terhadap profesional keperawatan. Sebuah penelitian di Nigeria menemukan hasil yang sama bahwa profesi keperawatan adalah profesi yang paling mungkin menerima kekerasan dari para ODGJ (29). Para perawat yang bekerja dalam pelayanan kesehatan jiwa mengalami kemungkinan kekerasan lebih tinggi dari para ODGJ yang menyebabkan pengalaman trauma secara emosional (PTSD) bagi para perawat (30).

Pasung dan seklusi (isolasi) telah digunakan oleh keluarga dan masyarakat terhadap para ODGJ. Anggota keluarga atau masyarakat mengikat, merantai, atau menempatkan kaki penderita di dalam balok kayu. Perilaku ini terjadi pada ODGJ terutama dari daerah terpencil karena mereka merasa malu dan takut kepada ODGJ terutama karena risiko perilaku kekerasan oleh ODGJ (31). Penelitian ini juga menemukan bahwa pengobatan tradisional dan alternatif menjadi pilihan pertama oleh ODGJ dan keluarga mereka yang juga menimbulkan perilaku pada ODGJ dalam proses pengobatan tradisional-alternatif tersebut. ODGJ dibawa ke "orang-orang pintar" yang secara tidak manusiawi melakukan kekerasan fisik terhadap mereka sehingga mengakibatkan ketakutan dan pengalaman traumatis (20). Selain itu, ODGJ kadang-kadang dibawa ke rumah sakit tanpa persetujuan mereka. Di rumah sakit, mereka diikat atau dimasukkan kedalam ruang isolasi di RSJ jika mereka melakukan kekerasan. Hasil penelitian ini juga menemukan bahwa, para perawat dan staf di RSJ melakukan pengikatan atau isolasi terhadap pasien mereka. Suasana kerja dengan lingkungan yang memiliki risiko dan memungkinkan adanya perilaku kekerasan dari pasien menyebabkan para perawat melakukan tindakan pengikatan atau isolasi. Hasil penelitian terdahulu mengungkapkan bahwa terdapat pengaruh antara lingkungan kerja perawat dengan pelaksanaan praktek keperawatan di rumah sakit (32). Hasil penelitian lain menemukan hasil yang sama bahwa pasung atau isolasi sering digunakan untuk menangani pasien dengan perilaku kekerasan (33). Hasil penelitian ini juga menunjukkan bahwa ODGJ mengalami kekerasan dari anggota keluarga atau kerabat mereka. Kekerasan terhadap ODGJ sering terjadi dalam lingkungan keluarga dan bukan orang asing (11).

Hasil penelitian ini membuktikan bahwa ODGJ tidak hanya sebagai pelaku kekerasan, akan tetapi mereka juga adalah korban kekerasan dari orang lain. Satu studi sebelumnya menyatakan bahwa para ODGJ sering menjadi korban perilaku kekerasan (34). Kekerasan fisik terhadap ODGJ lebih tinggi dari pada populasi secara umum (37). Stigma dan stigmatisasi gangguan jiwa menciptakan rasa takut bagi para penderita yang diberikan label berbahaya oleh orang lain (35). Perasaan takut para ODGJ ini dapat meningkatkan isolasi sosial (36). Perasaan takut pada ODGJ terkait dengan kekerasan fisik saat menjalani pengobatan tradisional alternatif. Disamping itu pasien juga mengalami trauma akibat proses perawatan mereka di rumah sakit jiwa. Anggota masyarakat tempat para ODGJ tinggal memaksa penderita dan keluarganya untuk pergi ke rumah sakit jiwa agar penderita bisa dirawat.

\section{Perasaan Ketakutan (Fear)}

Penelitian ini mengungkapkan bahwa penderita dan orang disekitarnya mengalami perasaan ketakutan. Anggota keluarga, keluarga dan kerabat serta orang lain takut terhadap para ODGJ. Ketakutan keluarga ini terutama didasarkan pada potensi adanya perilaku kekerasan yang tidak bisa diprediksi (18). Stigma dan proses stigmatisasi tentang penyakit jiwa merupakan penyebab utama perasaan takut yang dirasakan oleh orang lain. Banyak anggapan bahwa ODGJ menimbulkan ancaman bagi keselamatan umum (19). Hasil penelitian lain menunjukkan bahwa stigmatisasi gangguan jiwa menciptakan rasa takut dan ODGJ diberi label orang yang berbahaya $(18,35)$. Disamping keluarga dan masyarakat penelitian ini juga menemukan bahwa para personil kesehatan terutama perawat takut terhadap pasien mereka. Rasa takut yang dialami oleh perawat dapat mempengaruhi hubungan perawat-pasien, yang 
menghambat pemberian asuhan keperawatan kepada penderita $(14-16,38)$.

Studi kualitatif dengan pendekatan Charmaz Constructive Grounded Theory (CCGT) ini memberikan pemahaman secara substantif dan mendalam bahwa stigma dan proses stigmatisasi menyebabkan perilaku kekerasan yang dilakukan oleh para ODGJ terhadap orang lain baik keluarga, teman, masyarakat umum dan tenaga kesehatan. Disisi lain, stigma dan proses stigmatisasi ini

\section{DAFTAR PUSTAKA}

1. Vos $T$, Flaxman $A D$, Naghavi $M$, et al. Years Lived with Disability (Ylds) For 1160 Sequelae of 289 Diseases and Injuries 1990-2010: A Systematic Analysis for the Global Burden of Disease Study 2010. Lancet. 2012; (380): 2163-2196.

2. Departemen Kesehatan Republik Indonesia. Riset Kesehatan Dasar-Riskesdas 2013. Jakarta: Badan Penelitian dan Pengembangan Kesehatan Depkes RI; 2013.

3. Kapungwe A, Cooper S, Mwanza J, et al. Mental Illness - Stigma and Discrimination in Zambia. African Journal of Psychiatry. 2010; 13(3): 192-203.

4. Lestari W dan Wardhani YF. Stigma dan Penanganan Penderita Gangguan Jiwa Berat yang Dipasung. Buletin Penelitian Sistem Kesehatan. 2014; 17(2): 157-166.

5. Parle S. How Does Stigma Affect People with Mental Illness? Nursing Times. 2012; 108(28): 12-14.

6. Purnama G, Yani DI, dan Sutini T. Gambaran Stigma Masyarakat terhadap Klien Gangguan Jiwa di RW 09 Desa Cileles Sumedang. Jurnal Pendidikan Keperawatan Indonesia. 2016; 2(1): 29-37.

7. Wirnata. 280 Tanya Jawab Mengenai Kesehatan Jiwa. Cetakan I. Jakarta: Rumah Sakit Jiwa Dr. Soeharto Heerdjan; 2012.

8. Keliat BA dan Akemat. Model Praktik Keperawatan Profesional Jiwa. Jakarta: EGC; 2010.

9. Varshney M, Mahapatra A, Krishnan V, Gupta R, and Deb KS. Violence and Mental IIIness: What Is the True Story? Journal of Epidemiology and Community Health. 2016; 70(3): 223-225.

10. Newman JM, Turnbull A, Berman BA, Et Al. Impact of Traumatic and Violent Victimization Experiences in Individuals with Schizophrenia and Schizoaffective Disorder. The Journal of Nervous and Mental Disease. 2010; 198(10): 708-714.

11. Latalova K, Kamaradova D, and Prasko J. Violent Victimization of Adult Patients with Severe Mental IIIness: A Systematic Review. Neuropsychiatric Disease and Treatment. 2014; 9(10): 1925-1939.

12. Katsikidou M, Samakouri M, Fotiadou M, et al. Victimization of the Severely Mentally III in Greece: The Extent of the Problem. The International Journal of Social Psychiatry. 2012; 59(7): 706-715.

13. Holmes D, Rudge T, Perron A, and St-Pierre I. Introduction (Re) Thinking Violence in Health Care juga menyebabkan perilaku kekerasan oleh orang lain terhadap para ODGJ di masyarakat bahkan dalam pelayanan kesehatan. Penelitian lanjut diperlukan untuk memahami bagaimana perspektif keluarga, dan masyarakat memandang stigma dalam kaitannya dengan perilaku kekerasan dan rasa takut terkait dengan ODGJ. Program-program anti-stigma perlu dilakukan untuk membantu mengurangi konsekuensi negatif stigmatisasi gangguan jiwa yaitu perilaku kekerasan dan rasa takut (39).

Settings: A Critical Approach. Farnham, Surrey, UK: Ashgate Publishing, Ltd; 2012.

14. Arnetz J, Hamblin L, Essenmacher L, Et Al. Understanding Patient-To-Worker Violence in Hospitals: A Qualitative Analysis of Documented Incident Reports. Journal of Advanced Nursing. 2014; 71(2): 338-348.

15. Jacob JD and Holmes D. Working Under Threat: Fear and Nurse-Patient Interactions in a Forensic Psychiatric Setting. Journal of Forensic Nursing. 2011; 7(2): 68-77.

16. Jonker E, Goossens P, Steenhuis I, and Oud N. Patient Aggression in Clinical Psychiatry: Perceptions of Mental Health Nurses. Journal of Psychiatric and Mental Health Nursing. 2008; 15(6): 492-499.

17. Brian S. Mental Illness Stigma in the Media. The Review: A Journal of Undergraduate Student Research. 2015; (16): 50-63.

18. Araujo BY and Borrell LN. Understanding the Link between Discrimination, Mental Health Outcomes, and Life Chances among Latinos. Hispanic Journal of Behavior Sciences. 2012; 28(2): 245-266.

19. Jorm AF and Griffiths KM. The Public's Stigmatizing Attitudes towards People with Mental Disorders: How Important are Biomedical Conceptualizations? Acta Psychiatrica Scandinavica. 2008; 118(4): 315-321.

20. Subu MA. Pemanfaatan Terapi Tradisional dan Alternatif oleh Penderita Gangguan Jiwa. Jurnal Keperawatan Padjadjaran. 2015; 3(3): 193-203.

21. Charmaz K. Constructing Grounded Theory. 2nd edition. London: Sage Publications; 2014.

22. Subu MA. A Reflection of Adopting Paillé's Data Analysis in Constructivist Grounded Theory Research. World Wide Journal of Multidisciplinary Research and Development. 2017;3(7): 314-318.

23. Howard-Payne L. Glaser or Strauss? Considerations for Selecting a Grounded Theory Study. South African Journal of Psychology. 2016; 46(1): 50-62.

24. Subu MA, Holmes D, Elliot J, and Jacob JD. Persistent Taboo: Understanding Mental Illness and Stigma among Indonesian Adults through Grounded Theory. Asian Journal of Pharmacy, Nursing and Medical Sciences. 2017; 5(1): 1-11.

25. University of Manchester. National Confidential Inquiry into Suicide and Homicide by People with Mental Illness: Annual Report 2015: England, Northern Ireland, Scotland and Wales July 2015. 
Manchester: University of Manchester; 2015.

26. Kyaga $\mathrm{S}$, Landén $\mathrm{M}$, Boman $\mathrm{M}$, et al. Mental IIlness, Suicide and Creativity: 40-Year Prospective Total Population Study. Journal of Psychiatry Research. 2013; 47(1): 83-90.

27. Choe JY, Teplin LA, and Abram KM. Perpetration of Violence, Violent Victimization, and Severe Mental IIIness: Balancing Public Health Outcomes. Psychiatric Services. 2008; 59(2): 153-164.

28. Wehring $\mathrm{HJ}$ and Carpenter WT. Violence and Schizophrenia. Schizophrenia Bulletin. 2011; 37(5): 877-878.

29. James BO, Isa EW, and Oud N. Patient Aggression in Psychiatric Services: The Experience of a Sample of Nurses at Two Psychiatric Facilities in Nigeria. African Journal of Psychiatry. 2011; 14(2): 130-133.

30. Jacobowitz W. PTSD in Psychiatric Nurses and other Mental Health Providers: A Review of the Literature. Issues in Mental Health Nursing. 2013; 34(11): 787795.

31. Daulima NHC. Proses Pengambilan Keputusan Tindakan Pasung oleh Keluarga terhadap Klien Gangguan Jiwa. [Disertasi]. Fakultas IImu Keperawatan Universitas Indonesia, Depok. 2014.

32. Putra KR, Hamid AYS, dan Mustikasari. Pengaruh
Lingkungan Kerja Perawat Terhadap Pelaksanaan Praktek Keperawatan Di Rumah Sakit Umum Dr. SaifuL Anwar Malang Tahun 2006. Jurnal Kedokteran Brawijaya. 2007; 8(1): 50-54.

33. Wijayanti AP dan Masykur AM. Lepas Untuk Kembali Dikungkung: Studi Kasus Pemasungan Kembali Eks Pasien Gangguan Jiwa. Jurnal Empati. 2016; 5(4): 786-798.

34. Maniglio R. Severe Mental Illness and Criminal Victimization: A Systematic Review. Acta Psychiatrica Scandinavica. 2009 Mar; 119(3): 180-191.

35. Hsu CC, Sheu CJ, Liu SI, Sun YW, Wu SI, and Lin Y. Crime Victimization of Persons with Severe Mental Illness in Taiwan. The Australian and New Zealand Journal of Psychiatry. 2009; 43(5): 460-466.

36. Bathje GJ and Pryor JB. The Relationship of Public and Self-Stigma to Seeking Mental Health Services. Journal of Mental Health Counseling. 2011; 33(2): 161-176.

37. Dingfelder SF. Stigma: Alive and Well. American Psychological Association Monitor. 2009; 40(6): 56-60.

28. Subu MA, Esti A, Fernandes F, Fatmadona $R$, and Sasmita $\mathrm{H}$. Between Us and Them-Understanding Stigma and Stigmatization among People with HIV/AIDS in Sumatra Island Indonesia. ASEAN Journal of Psychiatry. 2017; 18(1): 1-13. 